\title{
Predictors of Early Reading Acquisition in Children of Low Socioeconomic Status
}

\author{
César Augusto Collazos-Campo ${ }^{1}$ \\ Natalia Cadavid-Ruiz ${ }^{1}$ \\ Juan Daniel Gómez ${ }^{2}$ \\ Sebastián Jiménez-Jiménez \\ María Cristina Quijano-Martínez
}

\begin{abstract}
The aim of the present study was to identify the predictors of early-grade reading acquisition in monolingual speakers of a transparent language. Eighty students attending preschool $(M=5$ years, $S D=0.40)$, first grade $(M=6$ years, $S D=0.59)$ and second grade $(M=7$ years, $S D=0.55)$ in a public institution participated in the study. All were evaluated with the Early Grade Reading Acquisition test, an ad hoc sociodemographic questionnaire and the language domain of the Child Neuropsychological Assessment battery. Multiple regression analysis showed that phonological awareness and years of education are the factors that explain reading performance of children in their early years of school. These findings highlight the importance of improving oral skills prior to early reading acquisition and contribute to enhancing the early reading skills of monolingual children with limited socioeconomic opportunities.
\end{abstract}

Keywords: reading skills, word recognition, children, phonological awareness

\section{Preditores da Leitura Inicial em Crianças de Baixa Condição Socioeconômica}

\begin{abstract}
Resumo: O presente estudo teve como objetivo identificar os preditores da leitura inicial de uma linguagem transparente em crianças monolíngues. Oitenta alunos pertencentes à educação infantil N3 $(M=5$ anos, $D E=0.40), 1^{\mathrm{a}}$ série $(M=6$ anos, $D E=0.59)$ e $2^{\text {a }}$ série $(M=7$ anos, $D E=0.55)$ do ensino fundamental participaram do estudo. As crianças foram avaliadas por meio do teste Early Grade Reading Acquisition, por um questionário sociodemográfico ad hoc e apenas pelo Domínio da Linguagem do teste Evaluación Neuropsicológica Infantil. A análise de regressão múltipla mostrou que a consciência fonológica e o nível de escolaridade são os fatores que explicam o desempenho na leitura em crianças nas primeiras séries. Os resultados deste estudo sugerem a importância de promover habilidades orais antes da aquisição da leitura inicial, para melhorar o aprendizado da leitura de crianças monolíngues com limitadas oportunidades socioeconômicas.
\end{abstract}

Palavras-chave: habilidades para leitura, reconhecimento de palavras, crianças, consciência fonológica

\section{Predictores de la Lectura Inicial en Niños de Condiciones Socioeconómicas Bajas}

\begin{abstract}
Resumen: El presente estudio tuvo por objetivo identificar los predictores de la lectura inicial en niños monolingües de un lenguaje transparente. Ochenta estudiantes que cursaban los grados de transición $(M=5$ años, $D E=0.40)$, primero $(M=6$ años, $D E=0.59)$ y segundo de primaria $(M=7$ años, $D E=0.55)$ en una institución pública, participaron en el estudio. Todos fueron evaluados con la prueba Early Grade Reading Acquisition, un cuestionario sociodemográfico ad hoc y el dominio de Lenguaje de la batería Evaluación Neuropsicológica Infantil. Los análisis de regresión múltiple mostraron que la conciencia fonológica y el grado de escolaridad son los factores que explican el desempeño lector de niños de los primeros grados escolares. Estos hallazgos destacan la importancia de promover habilidades orales previas a la adquisición de la lectura inicial, para mejorar el aprendizaje lector de niños monolingües, con limitadas oportunidades socio-económicas.
\end{abstract}

Palabras clave: habilidades para la lectura, reconocimiento de palabras, niños, conciencia fonológica

${ }^{1}$ Pontificia Universidad Javeriana - Cali campus, Cali, Colombia

${ }^{2}$ Pontificia Universidad Javeriana, Bogotá, Colombia

Support: Manuscript produced from research results, funded by Pontificia Universidad Javeriana de Cali, code 00004370.

Correspondence address: Natalia Cadavid-Ruiz. Pontificia Universidad Javeriana. Calle 18 \# 118-250, Cali 760032, Colombia.

E-mail: ncadavid@javerianacali.edu.co
Early-grade reading acquisition is one of the first steps to acquiring the cognitive resources necessary for the comprehension of written language (Bosse, 2015; Bravo, Villalón, \& Orellana, 2011; Caravolas et al., 2019). Several authors define it as the acquisition of grapheme-to-phoneme conversion rules, an indispensable part of the requirements to learn to decode written texts and, subsequently, understand 
them (Bravo Valdivieso, 2016; De la Calle, Guzmán-Simón, \& García- Jiménez, 2018; Gutiérrez, 2017; Jiménez, 2009; Perfetti \& Stafura, 2014). Early reading usually covers the first two years of formal education for reading transparent languages, being longer in the case of opaque languages (Caravolas et al., 2019; Godoy, Pinheiro, \& Citoler, 2017; Müller \& Brady, 2001). This means that languages with greater correspondence between their phonemes and graphemes tend to be associated with faster learning rates for early decoding skills (Caravolas et al., 2019; Diuk \& Ferroni, 2013).

For its proper acquisition, early reading is based on the development of oral language (e.g., naming speed and letter-sound knowledge; Escobar \& Meneses, 2014) and the metalinguistic ability known as phonological awareness (Cuetos Vega, 2017; Goswami, 2002). This ability is considered an indispensable requirement to relate each of the basic sound units that make up a word with the letters that correspond to each of these sounds. Over time, it is expected that these relationships facilitate automatic word recognition so that reading is accurate and fluid and that cognitive effort can be focused on understanding content (Cuetos, Suárez-Coalla, Molina, \& Llenderrozas, 2015; Fajardo Hoyos, Hernández Jaramillo, \& González Sierra, 2012; Goswami, 2002) by integrating lexical processes developed during early reading with grammatical processes, which requires interacting with mental models and the reader's ability to memorize (Perfetti \& Stafura, 2014).

Several studies have shown that some of the skills acquired in early reading favor reading performance for text comprehension. These skills are phonemic awareness, segmentation of syllables and words, naming speed, spelling of nonwords and alphabet knowledge (Diamanti et al., 2017; Godoy etal.,2017; Goswami, 2002; Gutiérrez, 2017; Ouellette \& Sénéchal, 2017; Stappen \& Van Reybroeck, 2018). Some studies suggest that phonological and phonemic awareness are the most important predictors of reading performance in the first years of this learning, while naming speed and reading of words and nonwords are better predictors of advanced learning focused on reading comprehension (Caravolas et al., 2019; Diuk \& Ferroni, 2013).

The modulating role of these skills has been suggested for both transparent (Finnish, Spanish, Italian and Greek) and opaque (English and French) languages in children between preschool and fifth grade (Bravo-Valdivieso, Villalón, \& Orellana, 2006; Caravolas et al., 2019; De Freitas, Mota, \& Deacon, 2018; Diamanti et al., 2017; Diuk \& Ferroni, 2013; Godoy et al., 2017; González Seijas, Cuetos Vega, López Larrosa, \& Vilar Fernández, 2017; Mcllraith \& Language and Reading Research Consortium, 2016; Ouellete \& Senechal, 2017; Soodla et al., 2015; Stappen \& Van Reybroeck, 2018). However, there are a few studies that show differences in the development of these reading skills in children from different socioeconomic contexts (Bravo-Valdivieso et al., 2006; Diuk \& Ferroni, 2013; Escobar \& Meneses, 2014; González Seijas et al., 2017).

This line of research has been widely developed in opaque languages such as English. The findings of previous studies show that environmental factors, such as the education level achieved by parents and the socioeconomic context of families, in particular, their reading practices, can explain $30 \%$ of the reading performance of children who learn to read (Ozernov-Palchik et al., 2019). Furthermore, Ouellette and Sénéchal (2017) highlight that the greater is the emphasis on oral language skills in the school curriculum of the early grades of elementary school education, the higher the performance in early grade reading acquisition.

The studies by Bravo-Valdivieso et al. (2006), Diuk and Ferroni (2013) and González Seijas et al. (2017) showed that monolingual transparent language-speaking children from low-income families present a slower acquisition of early reading skills. These authors suggest that these children will require the same time it takes for a child who speaks an opaque language to learn to decode their written language. This means that children of low socioeconomic status will have lower performance in their acquisition of reading in relation to their peers from more privileged socioeconomic contexts. In addition, Bravo-Valdivieso et al. (2006) and Diuk and Ferroni (2013) point out that the low level of phonological awareness and alphabetical knowledge of children with limited socioeconomic resources (e.g., limited access to learning opportunities in the neighborhoods where the children's homes are located and the occupation and education level of their parents, among others) may be factors that explain the longer time needed by these children to perform adequately in early reading. Usually, these studies have been conducted with school children between 4 and 7 years of age, a period in which they are expected to acquire basic reading skills.

The goal of the present study is to contribute to the line of research that explores the possible predictors of early reading of Spanish in monolingual children of low socioeconomic status. Therefore, this research aimed to identify the predictors of early reading in monolingual speakers of a transparent language. In particular, possible factors that predict the development of early reading in children from low socioeconomic strata were explored, according to the age, education and sex of the participants, parental education, and the children's levels of phonological awareness, comprehension and oral language expression. For this study, the low socioeconomic stratum is based on the socioeconomic stratification carried out by the Colombian government to identify those households with specific needs for the provision of public services and infrastructure, in addition to determining access to labor, the quality of education and health services, and access to cultural learning and leisure opportunities (Departamento Administrativo Nacional de Estadística [DANE], 2019).

\section{Method}

\section{Participants}

One hundred and twenty-two students who were in preschool and first and second grades of a public institution 
located in a lower-middle socioeconomic area in the city of Santiago de Cali were selected via nonprobabilistic discretional convenience sampling. Of the total students, 80 met the following inclusion criteria: (a) attended school regularly; (b) achieved a score equal to or greater than 80 on the Test of Nonverbal Intelligence (TONI-2); and (c) was in the first two years of formal learning of reading, either in preparation for the acquisition of literacy (preschool), at the beginning of their learning (first grade) or with one year of experience in this learning (second grade). The only exclusion criterion was presenting a diagnosis of psychiatric or neurological disease. Table 1 provides the sociodemographic characteristics of the final sample.

Table 1

Sociodemographic data of the final sample by grade level $(n=80)$

\begin{tabular}{|c|c|c|c|c|}
\hline \multicolumn{2}{|c|}{ Characteristics } & $\begin{array}{c}\text { Preschool } \\
f\end{array}$ & $\begin{array}{c}\text { First } \\
f\end{array}$ & $\begin{array}{c}\text { Second } \\
f\end{array}$ \\
\hline \multirow{2}{*}{ Sex } & Male & 11 & 17 & 16 \\
\hline & Female & 10 & 11 & 15 \\
\hline Age & $M(S D)$ & $5(0.40)$ & $6(0.59)$ & $7(0.55)$ \\
\hline IQ & $M(S D)$ & $100.7(11.44)$ & $105(10.80)$ & $101(10.58)$ \\
\hline $\begin{array}{l}\text { Parental } \\
\text { education }\end{array}$ & $M(S D)$ & $11.29(2.63)$ & $11.72(2.61)$ & $12.36(1.19)$ \\
\hline
\end{tabular}

According to these criteria, 14 participants were excluded due to having an IQ lower than 80 , three reported neurological or psychiatric diagnoses, one was disabled on the day of the assessment, 12 withdrew from school weeks after screening, nine did not complete the consent for or provide their assent to participate in the study, and three reported not being interested in participating on the day of the assessment.

The final groups did not show significant differences in their IQ $(F[2.77]=1.304, p=0.277)$. The education level of the parents varied between 3 and 17 years of schooling, with a mean of 11.51 years $(S D=2.23)$.

\section{Instruments}

The TONI-2 and the language domain of the Child Neuropsychological Assessment 2 (ENI-2) battery were used as screening tests. The first sought to select students who presented average intellectual performance (Brown, Sherbenou, \& Johnsen, 2009), while the second sought to describe the oral language performance of the participants, taking into account that the acquisition of reading and writing depends on the level of development reached in oral language (Matute, Rosselli, Ardila, \& Ostrosky, 2013).

Nonverbal Intelligence Test (TONI-2) - The TONI-2 is a single-choice, nonverbal intelligence test that is administered in 20 minutes to people between 5 and 85 years of age, developed and validated in the North American population. The purpose of the instrument is to measure the ability to solve, through the identification of sequences, abstract problems (Brown et al., 2009). The Spanish version has reliability indices, calculated with Cronbach's alpha, for different age ranges (from 0.81 to 0.94 ). In addition, it has convergent validity (0.66) with the WISC-R battery.

Child Neuropsychological Assessment 2 (ENI-2) - The ENI-2 examines the neuropsychological development of Spanish-speaking children and adolescents between 5 and 16 years of age. This battery evaluates 12 cognitive processes and academic skills that can be applied together or separately. For this study, the oral language dimension was used. This dimension consists of three subdomains: repetition (syllables, words, nonwords and sentences), comprehension (divided into the tests on image pointing, oral commands and discourse comprehension) and expression (tested through image naming, narrative coherence and utterance length). The direct score of each of these subdomains can be converted to a percentile for interpretation (Matute et al., 2013).

With respect to its psychometric properties, the ENI-2 reports a test-retest reliability between 0.13 and 0.71 , in addition to a reliability between qualifiers ranging from 0.85 to 0.98 for its different tests. Language proficiency has a stability coefficient of 0.91 .

Early Grade Reading Assessment (EGRA) - The EGRA was administered to evaluate the early reading level of the participants (Jiménez, 2009). This test was constructed at the request of international institutions such as the World Bank and the United States Agency for International Development to have a simple low-cost and effective measure to diagnose levels of early reading skill acquisition. The EGRA is divided into eight sections, which are detailed in Table 3. This test determines the level of knowledge acquired associated with the reading of phonemes (sounds), letters, words, nonwords, and sentences and the comprehension of short text. To do this, the first five subtests are each completed within 60 seconds, after which the number of correct items summed. The comprehension subtests evaluate the capacity of the evaluated person to correctly answer five questions after having been read to or having read a short story of no more than 60 words. The dictation subtest evaluates the accuracy of writing, at the orthographic and grammatical levels, a 12 -word sentence that is dictated to the person evaluated. The phonological awareness test consists of two subtests: identification of the initial sound and identification of words that begin with the same sound. Both tests were applied to evaluate the ability of participants to consciously manipulate the smallest and most meaningless units of oral language, in particular, phonemes (Jiménez, 2009).

The validity and reliability of the EGRA in Nicaragua and Honduras was determined. The results showed that the test has a high level of reliability between the same subtests, in addition to presenting moderately high internal consistency. In terms of validity, the EGRA presents high levels of correlation between its different subtests (Bazán, 2010). For the purposes of this work, the EGRA was adapted for use in Colombia. This consisted of the review and adjustment of linguistic and cultural factors by two experts in the area of language and child neuropsychology to evaluate the content validity of the aforementioned test. Once the corrections were adopted, a pilot 
test was carried out to finalize the presentation of instructions and test content used in this work.

\section{Procedure}

Data collection. Once the school's endorsement of the study was obtained, a list of the students who met the inclusion criteria was reviewed with the school's administration, and a presentation regarding the project was given to the children's parents, followed by a request to provide consent for their children's participation. In addition to presenting the objective of the study, ethical considerations for the development of the study are specified and detailed below.

Subsequently, an agreement was made between the project evaluators and the professors of the institution to establish test administration schedules. The screening and assessment were carried out in the school's facilities in a space suitable for this purpose; four psychologists previously trained in the application and scoring of the instruments conducted the screening and assessment. The screening lasted approximately 20 minutes per student, during which the TONI-2 and the language domain of the ENI-2 battery were applied.

In a second assessment period, the EGRA was applied along with other tests for a broader project. This assessment took approximately 30 minutes per participant.

Data analysis. Descriptive statistics were calculated as the mean, standard deviation and median of the scores of the participants in both the screening tests and the EGRA. In the case of oral language skills evaluated with the ENI-2, the percentiles obtained by each of the school grades that participated in the study are reported. In the case of the EGRA test, its direct scores are reported.

The comparison of reading performance by school grade was performed with single-factor ANOVA ( $F$-statistic), when the data showed a normal distribution, or with the KruskalWallis ( $H$ test), when the data did not meet this assumption. The post hoc analyses were carried out with the Bonferroni correction method. The extent of the relationship between variables was identified to perform multiple regression analysis to establish the factors that explain the reading acquisition of children in the school grades explored in this work. For these models, each of the early reading skills measured by the EGRA was used as the dependent variable. The predictive variables included the education level of the parents, the age, schooling, and sex of the participants, and the levels of phonological awareness and comprehension and oral expression of the language of the participants according to the variables that other studies found relevant in explaining the development of reading acquisition in children.

\section{Ethical Considerations}

This study was approved by the ethics committee of an educational institution under Act number 68 in the session held on April 11, 2016. Among its considerations, it was ensured that participation was voluntary, that the processing of data would be confidential, and that the participants could withdraw from the study at any time and would not receive monetary compensation, apart from the contribution to the school for participating in this study. It was also clarified that the risks of the study were minimal, as established by resolution No. 8.430 of the Ministry of Health (1993), established in 1993, and Law No. 1.090 (2006).

\section{Results}

Before presenting the predictors of early reading acquisition in monolingual transparent-language speaking children of a low socioeconomic status, the level of oral skills and phonological awareness of the sample evaluated will be presented to identify the level of development reached by the sampled children in the oral language skills that are considered essential to begin early reading acquisition. Subsequently, the level of performance achieved by children in these skills is compared, according to their school grade, so that it can be established whether the formal learning of reading changes with years of education, at least in the first two years, as reported in the literature on the early learning of transparent languages such as Spanish. These results will allow us to better understand the regression analyses presented at the end of this section to identify the variables that predict the early reading level of monolingual children with limited socioeconomic resources.

The analysis of oral language skills of the study participants is shown in Table 2. The sample reached an expected level of performance, according to the ENI scoring and interpretation standards, both for comprehension and for the expression of oral language, with performance being very similar among the three school grades evaluated. However, performance tended to be within the lower expected levels. Notably, children in second grade, compared to those in the previous two grades, showed a significant difference in their performance in repetition tasks; the average score obtained by children in preschool and first grade was 46.36 , while the average score for children in second grade was 31.24 $(p=0.036)$. One of the possible reasons for this difference is that children in second grade maintained a direct score similar to that of children of younger ages, which the subtest scores more strictly; therefore, they obtained a lower percentile than that obtained by the children in lower grades.

Regarding their level of phonological awareness, children improved their ability to discriminate discrete sounds from Spanish and manipulate these sounds as their grade level increased. As Table 2 shows, preschool children showed little ability in their phonological awareness, but this ability significantly increased in the first grade of primary education and was maintained in second grade. These results are supported by the significant differences observed between the preschool children and the other two school grades in the post hoc analyses performed with the Bonferroni correction method. In the phonological awareness subtest to identify initial sounds, significant differences were found between children in preschool 
$(M d n=1.29)$ andfirstgrade $(M d n=6.61)(p<0.001)$, while for the task of identifying the same sound, there were differences between children in preschool $(M d n=3.43)$ and first grade $(M d n=5.57)(p=0.002)$ and between children in preschool $(M d n=3.43)$ and second grade $(M d n=5.65)(p=0.006)$.
The performance of the participants on the EGRA early reading test is detailed in Table 3 . There, better performance can be observed as a function of years of schooling, where the preschool children showed very low performance because they had not formally started learning to read.

Table 2

Performance of the sample on oral language and phonological awareness tests, by grade level

\begin{tabular}{|c|c|c|c|c|c|}
\hline Oral tests & $\begin{array}{c}\text { Preschool } \\
M(S D)\end{array}$ & $\begin{array}{c}\text { First } \\
M(S D)\end{array}$ & $\begin{array}{l}\text { Second } \\
M(S D)\end{array}$ & \multicolumn{2}{|c|}{ Comparison of means ${ }^{\mathrm{a}}$} \\
\hline \multicolumn{6}{|l|}{ ENI } \\
\hline Repetition & $\begin{array}{c}53.29(6.59) \\
63\end{array}$ & $\begin{array}{c}53.96(5.92) \\
63\end{array}$ & $\begin{array}{c}32.41(4.76) \\
16\end{array}$ & $H=8.15$ & $p=0.017$ \\
\hline Comprehension & $\begin{array}{c}45.00(5.65) \\
37\end{array}$ & $\begin{array}{c}35.89(3.70) \\
37\end{array}$ & $\begin{array}{c}45.03(4.26) \\
50\end{array}$ & $F(2,77)=1.44$ & $p=0.244$ \\
\hline Expression & $\begin{array}{c}41.71(4.45) \\
37\end{array}$ & $\begin{array}{c}34.86(4.23) \\
37\end{array}$ & $\begin{array}{c}28.26(4.64) \\
16\end{array}$ & $F(2,77)=2.11$ & $p=0.128$ \\
\hline \multicolumn{6}{|l|}{ EGRA } \\
\hline Phonological awareness, initial sound identification & $\begin{array}{c}1.29(0.42) \\
0.00\end{array}$ & $\begin{array}{c}6.61(0.60) \\
7.50\end{array}$ & $\begin{array}{c}5.29(0.46) \\
6.00\end{array}$ & $H=30$ & $p<0.001$ \\
\hline Phonological awareness, same sound identification & $\begin{array}{c}3.43(0.34) \\
3.00\end{array}$ & $\begin{array}{c}5.57(0.45) \\
6.00\end{array}$ & $\begin{array}{c}5.65(0.46) \\
5.00\end{array}$ & $H=13.18$ & $p=0.001$ \\
\hline
\end{tabular}

Note. The values of the ENI test are given in percentiles; those of the EGRA test refer to direct scores. ${ }^{\mathrm{a}} F=\mathrm{ANOVA} ; H=\mathrm{Kruskal}-\mathrm{Wallis}$ nonparametric test.

Table 3

Level of early reading performance, by grade level

\begin{tabular}{|c|c|c|c|}
\hline \multirow{2}{*}{ EGRA $^{\mathrm{a}}$} & Preschool & First & Second \\
\hline & $M(S D)$ & $M(S D)$ & $M(S D)$ \\
\hline Sounds & $1.95(4.47)$ & $10.43(9.83)$ & $10.19(6.80)$ \\
\hline Letters & $3.52(8.64)$ & $31.32(18.93)$ & $41.84(13.32)$ \\
\hline Words & $1.67(5.70)$ & $32.68(20.34)$ & $49.40(16.77)$ \\
\hline Nonwords & $0.90(3.35)$ & $22.06(13.36)$ & $34.21(12.31)$ \\
\hline Reading & $3.81(16.08)$ & $40.86(27.59)$ & $70.83(25.22)$ \\
\hline Reading comprehension & $0.19(0.87)$ & $2.54(1.55)$ & $4.03(1.11)$ \\
\hline Oral comprehension & $1.67(1.56)$ & $1.96(1.29)$ & $3.03(1.56)$ \\
\hline Dictation & $0.62(2.84)$ & $7.50(3.84)$ & $10.06(2.86)$ \\
\hline
\end{tabular}

Note. ${ }^{\text {Direct scores. }}$

Regression analyses were conducted for each of the early reading skills measured by the EGRA. The predictive variables considered were the age, education and sex of the participants, the level of education of their parents, and the children's levels of phonological awareness, comprehension and expression of oral language.

The results showed that the performance of children in early reading tasks depends on two variables: years of schooling and their level of phonological awareness. These two variables were able to explain six of the eight tests that measure early reading performance. Notably, these six models met the assumptions for performing regression analysis. In particular, the following were observed: (a) linearity and homoscedasticity of the data, upon inspecting studentized residual plots; (b) independence of the residuals, by obtaining values of the Durbin-Watson statistic between 1.5 and 2.2; (c) Cook's distance values less than 1; (d) influence measures less than 0.2 ; (e) absence of multicollinearity, by finding tolerance values greater than 0.1 ; (f) studentized residuals $< \pm 3$; and (g) a normal distribution of the data upon visual inspection.

Year of schooling explained the number of correct sounds and letter names that children can name in one minute as well as the number of correct answers they can provide in the oral comprehension task. For its part, phonological awareness explained the number of words, nonwords and words of a paragraph that children can read in one minute. The regression coefficients are provided in Table 4. 
Table 4

Predictors of early reading performance in monolingual Spanish-speaking children who are starting to learn to read

\begin{tabular}{|c|c|c|c|c|c|c|}
\hline Variable & $F$ & $p$ & $R^{2}$ adjusted & $B$ & $\mathrm{SE}_{\beta}$ & $\beta$ \\
\hline Sounds read correctly per minute & 12.21 & 0.001 & 12.4 & & & \\
\hline Constant & & & & 3.81 & 1.51 & \\
\hline Schooling & & & & 3.82 & 1.09 & 0.37 \\
\hline Letters read correctly per minute & 76.48 & $<0.000$ & 48.9 & & & \\
\hline Constant & & & & 7.22 & 2.93 & \\
\hline Schooling & & & & 18.56 & 2.12 & 0.70 \\
\hline Words read correctly per minute & 29.68 & $<0.000$ & 26.6 & & & \\
\hline Constant & & & & 12.84 & 4.10 & \\
\hline Phonological awareness & & & & 3.87 & 0.71 & 0.52 \\
\hline Nonwords read correctly per minute & 25.56 & $<0.000$ & 23.7 & & & \\
\hline Constant & & & & 9.29 & 2.90 & \\
\hline Phonological awareness & & & & 2.54 & 0.50 & 0.50 \\
\hline Reading correctly per minute & 97.29 & $<0.000$ & 54.9 & & & \\
\hline Constant & & & & 5.32 & 4.65 & \\
\hline Phonological awareness & & & & 33.27 & 3.37 & 0.75 \\
\hline Oral comprehension & 11.77 & 0.001 & 12.0 & & & \\
\hline Constant & & & & 1.50 & 0.29 & \\
\hline Schooling & & & & 0.71 & 0.21 & 0.36 \\
\hline
\end{tabular}

Note. Source $=$ prepared by the authors.

As seen in Table 4, schooling explained between 12 and $48.9 \%$ of the basic skills of early reading, associated with the acquisition of grapheme-to-phoneme conversion rules that allow naming the individual elements forming oral and written language at the phonological level. Additionally, phonological awareness explained between 23.7 and $54.9 \%$ of the elements of early reading at the word level. Both factors reached an effect size varying between medium and large, according to Cohen (1988).

\section{Discussion}

The aim of this study was to identify possible factors that predict the development of early reading acquisition in monolingual children from low socioeconomic strata. The main finding is that children's phonological awareness and years of schooling are the most important factors for defining their level of performance in this academic learning. This result coincides, in part, with the findings of studies conducted with Latin American children with low socioeconomic resources: phonological awareness is one of the most relevant components in the early years of learning to read (Bravo-Valdivieso et al., 2006; Diuk \& Ferroni, 2013).

In this study, phonological awareness showed a moderate to strong predictive capacity to explain the learning of decoding written texts at the word level. In particular, this factor predicted the precision and fluency with which study participants read words, nonwords and short texts. These results also coincide with the visual recognition models of words, in which it is proposed that the early learning of reading should focus on the development of phonological processes of reading, in particular, appropriating grapheme-to-phoneme conversion rules, before emphasizing other processes such as the semantics and syntactics of this type of learning (Jiménez, 2009; Rueckl, 2016; Snowling, 2001). This result also coincides with studies that indicate that phonological awareness is a predictor of the early years of learning to read, independent of sociodemographic variables, such as the socioeconomic level and education level of the parents (Bravo et al., 2011; Diamanti et al., 2017; Mcllraith \& Language and Reading Research Consortium, 2016; Ozernov-Palchik et al., 2019). This finding should be carefully analyzed, considering that the phonological awareness test corresponds to the measure offered by the EGRA.

However, this study found that for the sample evaluated, level of education is also important in explaining the acquisition of alphabet knowledge and contributes to the understanding of language. Although this finding has not been reported in early reading literature, it is of great relevance considering that the study investigated a sample of children from low-income families. Therefore, this finding leads to the assumption that formal education becomes a space of teaching-learning opportunities crucial for reading acquisition for children of low socioeconomic strata, which other developmental contexts are not providing. This finding coincides with studies on early literacy that suggest that the sociolinguistic context in which a child is born and grows explains their future reading performance (Phillips \& Lonigan, 2009; Piacente, Marder, Resches, \& Ledesma, 2006; Stephenson, Parrila, Georgiou, \& Kirby, 2008). According to this approach, the socioeconomic and cultural conditions of the families of the participants of this study do not seem to be sufficient for them to develop the linguistic skills necessary for early reading acquisition.

This assumption could also be supported by two results of this study. The first is that in none of the regressions performed was the education level of parents able to explain the performance of their children in tasks related to early reading. The second corresponds to the performance of the participants 
on oral language tests. Their performance on these tests, despite being within the expected levels, was within the lower levels. In addition, notably, preschool children showed poor performance in phonological awareness tasks before starting to learn to read. With respect to this last result, it could be said that in preschool, children still do not reach the minimum level of prereading skills to support early reading acquisition.

Taken together, the results of this study suggest the need for children from low socioeconomic strata to have access to early language stimulation programs, aimed at the family or educational context. These programs should focus on improving oral language skills, such as phonological awareness, which are considered prerequisites for the appropriate learning of reading. The next teaching goal should focus on early reading, such as, knowledge of the structure of words, their sounds, spelling, word segmentation, etc., while continuing to work on oral language skills linked to strengthening vocabulary. This route requires work, at least during the first years of primary basic education, because as the results of this study show, at the end of second grade, it is still necessary to improve learning of the basic skills for early reading. This result is in line with Diuk and Ferroni (2013), who argue that Spanish monolingual children with limited socioeconomic resources have a slower early reading acquisition pace.

Future studies on the predictive factors of early reading performance should be carried out with long-term designs and larger sample sizes that include students from different socioeconomic backgrounds so that the current findings on the first years of reading acquisition can be contrasted. In addition, this line of research would benefit from the joint study of early reading skills (learning to read) and text comprehension (reading to learn) so that empirical evidence is offered on two topics of high interest for literacy studies that are usually studied in isolation. Additionally, it is important to carefully select the instruments to be used to measure oral language, prereading and early reading skill performance. Future research should focus on the follow-up of school-aged children, from different sociocultural conditions and that included the number of years dedicated to learning early skills and more complex such as the one related to reading comprehension, so to find sufficient evidence of the role of social factors in the development of language and early reading acquisition.

\section{References}

Bazán, J. (2010). Análisis psicométrico de EGRA y su validez concurrente con otras evaluaciones de desempeño en lectura: Caso Honduras y Nicaragua [EGRA psychometric analysis of the EGRA and its concurrent validity with other reading assessments: The case of Honduras and Nicaragua]. Research Triangle Park, NC: RTI International. Retrieved from https:// www.globalreadingnetwork.net/sites/default/files/media/file/ ValidezConcurrente_final_15marzo2011.pdf
Bosse, M.-L. (2015). Learning to read and spell: How children acquire word orthographic knowledge. Child Development Perspectives, 9(4), 222-226. doi: 10.1111/cdep.12133

Bravo, L., Villalón, M., \& Orellana, E. (2011). La conciencia fonológica y la lectura inicial en niños que ingresan a primer año básico [Phonological awareness and emergent reading in children who enter first elementary grade]. Psykhe, 11(1), 175-182. Retrieved from http://www. psykhe.cl/index.php/psykhe/article/view/452/431

Bravo Valdivieso, L. (2016). El aprendizaje del lenguaje escrito y las ciencias de la lectura. Un límite entre la psicología cognitiva, las neurociencias y la educación [Learning written language and sciences of reading. A boundary between cognitive psychology, neuroscience and education]. Límite. Revista Interdisciplinaria de Filosofia y Psicología, 11(36), 50-59.

Bravo-Valdivieso, L., Villalón, M., \& Orellana, E. (2006). Predictibilidad del rendimiento en la lectura: Una investigación de seguimiento entre primer y tercer año [Predictability of reading performance: A follow up study between first and third grades]. Revista Latinoamericana de Psicología, 38(1), 9-20. Retrieved from http://www. scielo.org.co/pdf/rlps/v38n1/v38n1a01.pdf

Brown, L., Sherbenou, R., \& Johnsen, S. (2009). TONI2, test de inteligencia no verbal: Apreciación de la habilidad cognitiva sin influencia del lenguaje [TONI2, non-verbal intelligence test: Appreciation of this cognitive ability without language influence]. Madrid, España: TEA Ediciones.

Caravolas, M., Lervåg, A., Mikulajová, M., Defior, S., SeidlováMálková, G., \& Hulme, C. (2019). A cross-linguistic, longitudinal study of the foundations of decoding and reading comprehension ability. Scientific Studies of Reading, 23(5), 386-402. doi:10.1080/10888438.2019.1580284

Cohen, J. (1988). Statistical power analysis for the behavioral sciences (2nd ed.). New York, NY: Psychology Press.

Cuetos, F., Suárez-Coalla, P., Molina, M. I., \& Llenderrozas, M. C. (2015). Test para la detección temprana de las dificultades en el aprendizaje de la lectura y escritura [Test for the early detection of learning difficulties in reading and writing]. Pediatría Atención Primaria, 17(66), e99-e107. doi:10.4321/S1139-76322015000300002

Cuetos Vega, F. (2017). Cómo facilitar el aprendizaje de la lectura [How to facilitate reading acquisition]. Padres $y$ Maestros, (370), 61-67. doi:10.14422/pym.i370.y2017.010

Departamento Administrativo Nacional de Estadística. (2019). Estratificación socioeconómica. Retrieved from https://www. dane.gov.co/index.php/servicios-al-ciudadano/serviciosinformacion/estratificacion-socioeconomica\#preguntasfrecuentes 
De Freitas, P. V., Jr., Mota, M. M. P. E., \& Deacon, S. H. (2018). Morphological awareness, word reading, and reading comprehension in Portuguese. Applied Psycholinguistics, 39(3), 507-525. doi:10.1017/S0142716417000479

De la Calle, A. M., Guzmán-Simón, F., \& García-Jiménez, E. (2018). El conocimiento de las gráficas y la secuencia de aprendizaje de los grafemas en español: Precursores de la lectura temprana [Letter knowledge and learning sequence of graphemes in Spanish: Precursors of early reading]. Revista de Psicodidáctica, 23(2), 128-136. doi:10.1016/j.psicod.2017.10.002

Diamanti, V., Mouzaki, A., Ralli, A., Antoniou, F., Papaioannou, S., \& Protopapas, A. (2017). Preschool phonological and morphological awareness as longitudinal predictors of early reading and spelling development in Greek. Frontiers in Psychology, 8, 2039. doi:10.3389/fpsyg.2017.02039

Diuk, B., \& Ferroni, M. (2013). ¿Anglocentrismo en los modelos de adquisición lectora? Un estudio en una lengua de ortografía transparente [Anglocentrism in reading acquisition models? A study in a language with transparent orthography]. Suma Psicológica, 10(2), 29-39. Retrieved from http://pepsic.bvsalud.org/scielo.php?script=sci_ arttext\&pid=S0719-448x2013000200003

Escobar, J.-P., \& Meneses, A. (2014). Initial reading predictors in Spanish according to SES: Is semi-transparency sufficient to explain performance? Estudios de Psicología, 35(3), 625-635. doi:10.1080/02109395.2014.965458

Fajardo Hoyos, A., Hernández Jaramillo, J., \& González Sierra, A. (2012). Acceso léxico y comprensión lectora: Un estudio con jóvenes universitarios [Lexical access and reading comprehension: A study with university students]. Revista Electrónica de Investigación Educativa, 14(2), 25-33. Retrieved from http://www.scielo.org.mx/scielo.php?script=sci_ arttext\&pid $=$ S1607-40412012000200003

Godoy, D. M. A., Pinheiro, A. M. V., \& Citoler, S. D. (2017). Initial literacy: Influence of phonemic awareness and teaching method. Psicologia: Teoria e Prática, 19(3), 226241. doi:10.5935/1980-6906/psicologia.v19n3p226-241

González Seijas, R. M., Cuetos Vega, F., López Larrosa, S., \& Vilar Fernández, J. (2017). Efectos del entrenamiento en conciencia fonológica y velocidad de denominación sobre la lectura. Un estudio longitudinal [Effects of fonological awareness and naming speed training on reading. A longitudinal study]. Estudios sobre Educación, 32, 155-177. doi:10.15581/004.32.155-177

Goswami, U. (2002). Phonology, reading development, and dyslexia: A cross-linguistic perspective. Annals of Dyslexia, 52(1), 141-163. doi:10.1007/s11881-002-0010-0
Gutiérrez, R. (2017). Habilidades favorecedoras del aprendizaje de la lectura en alumnos de 5 y 6 años [Favoring skills of learning to read in 5 and 6 years students]. Revista Signos Estudios de Lingüistica, 51(96), 45-60. doi:10.4067/S0718-09342018000100045

Jiménez, J. E. (Adap.). (2009). Manual para la evaluación inicial de la lectura en niños de educación primaria [Manual for the initial evaluation of reading in primary school children]. Research Triangle Park, NC: RTI International. Retrieved from https://pdf.usaid.gov/pdf docs/Pnads441.pdf

Ley No. 1.090. (2006, 6 de septiembre). Por la cual se reglamenta el ejercicio de la profesión de Psicología, se dicta el Código Deontológico y Bioético y otras disposiciones. Retrieved from https://www. funcionpublica.gov.co/eva/gestornormativo/norma_pdf. php?i $=66205$

Matute, E., Rosselli, M., Ardila, A., \& Ostrosky, F. (2013). Evaluación Neuropsicológica Infantil (ENI-2) [Children Neuropsychological Assessment (ENI-2)] (2nd ed.). Ciudad de México, México: Manual Moderno.

Mcllraith, A., \& Language and Reading Research Consortium. (2016). Predicting word reading ability: A quantile regression study. Journal of Research in Reading, 41(1), 79-96. doi:10.1111/1467-9817.12089

Ministerio de Salud. (1993). Resolución No. 8.430, de 4 de octubre. Por la cual se establecen las normas científicas, técnicas y administrativas para la investigación en salud. Retrieved from https://www.minsalud.gov.co/sites/rid/ Lists/BibliotecaDigital/RIDE/DE/DIJ/RESOLUCION8430-DE-1993.PDF

Müller, K., \& Brady, S. (2001). Correlates of early reading performance in a transparent orthography. Reading and Writing: An Interdisciplinary Journal, 14(7-8), 757-799. doi:10.1023/A:1012217704834

Ouellette, G., \& Sénéchal, M. (2017). Invented spelling in kindergarten as a predictor of reading and spelling in grade 1: A new pathway to literacy, or just the same road, less known? Developmental Psychology, 53(1), 77-88. doi: $10.1037 / \operatorname{dev} 0000179$

Ozernov-Palchik, O., Norton, E. S., Wang, Y., Beach, S. D., Zuk, J., Wolf, M., ... Gaab, N. (2019). The relationship between socioeconomic status and white matter microstructure in pre-reading children: A longitudinal investigation. Human Brain Mapping, 40(3), 741-751. doi:10.1002/hbm.24407

Perfetti, C., \& Stafura, J. (2014). Word knowledge in a theory of reading comprehension. Scientific Studies of Reading, 18(1), 22-37. doi:10.1080/10888438.2013.827687 
Phillips, B. M., \& Lonigan, C. J. (2009). Variations in the home literacy environment of preschool children: A cluster analytic approach. Scientific Studies of Reading, 13(2), 146-174. doi:10.1080/10888430902769533

Piacente, T., Marder, S., Resches, M., \& Ledesma, R. (2006). El contexto alfabetizador hogareño en familias de la pobreza. Comparación de sus características con las de familias no pobres [Home literacy context in low income families. Its comparation with families of higher socioeconomic status]. Revista Iberoamericana de Diagnóstico y Evaluación Psicológica, 21(1), 61-88. Retrieved from https://www. aidep.org/sites/default/files/articles/R21/R214.pdf

Rueckl, J. G. (2016). Toward a theory of variation in the organization of the word reading system. Scientific Studies of Reading, 20(1), 86-97. doi:10.1080/1088843 8.2015.1103741

Snowling, M. J. (2001). From language to reading and dyslexia. Dyslexia, 7(1), 37-46. doi:10.1002/dys.185

Stappen, C. V., \& Van Reybroeck, M. (2018). Phonological awareness and rapid automatized naming are independent phonological competencies with specific impacts on word reading and spelling an intervention study. Frontiers in Psychology, 9, 320. doi:10.3389/fpsyg.2018.00320

Stephenson, K. A., Parrila, R. K., Georgiou, G. K., \& Kirby, J. R. (2008). Effects of home literacy, parents' beliefs, and children's task-focused behavior on emergent literacy and word reading skills. Scientific Studies of Reading, 12(1), 24-50. doi:10.1080/10888430701746864

Soodla, P., Lerkkanen, M.-A., Niemi, P., Kikas, E., Silinskas, G., \& Nurmi, J.-E. (2015). Does early reading instruction promote the rate of acquisition? A comparison of two transparent orthographies. Learning and Instruction, 38, 14-23. doi:10.1016/j.learninstruc.2015.02.002

César Augusto Collazos-Campo is a Research Assistant in the research group BITACUS from the Social Sciences Department of Pontificia Universidad Javeriana, Cali, Colômbia.

Natalia Cadavid-Ruiz is a Professor in the Social Sciences Department of Pontificia Universidad Javeriana, Cali, Colômbia.

Juan Daniel Gómez is a Professor in the Faculty of Psychology of Pontificia Universidad Javeriana, Bogotá, Colômbia.

Sebastián Jiménez-Jiménez is a Professor in the Social Sciences Department of Pontificia Universidad Javeriana, Cali, Colômbia.

Maria Cristina Quijano-Martinez is a Professor in the Social Sciences Department of Pontificia Universidad Javeriana, Cali, Colômbia.
Authors' Contributions:

All authors made substantial contributions to the conception and design of this study, to data analysis and interpretation, and to manuscript revision and approved the final version. All the authors assume public responsibility for the content in the manuscript.

Received: Jun. 13, 2019

1st Revision: Nov. 07, 2019

2nd Revision: Mar. 06, 2020

Approved: Apr. 06, 2020
How to cite this article:

Collazos-Campo, C. A., Cadavid-Ruiz, N., Gómez, J. D., Jiménez-Jiménez, S., \& Quijano-Martínez, M. C. (2020). Predictors of early reading acquisition in children of low socioeconomic status. Paidéia (Ribeirão Preto), 30, e3037.doi:https://doi.org/10.1590/1982-4327e3037 